This item was submitted to Loughborough's Research Repository by the author.

Items in Figshare are protected by copyright, with all rights reserved, unless otherwise indicated.

\title{
Bank regulation, financial crisis and the announcement effects of seasoned equity offerings of US commercial banks
}

PLEASE CITE THE PUBLISHED VERSION

http://dx.doi.org/10.1016/j.jfs.2016.06.007

\section{PUBLISHER}

(C) Elsevier

\section{VERSION}

NA (Not Applicable or Unknown)

\section{PUBLISHER STATEMENT}

This work is made available according to the conditions of the Creative Commons Attribution-NonCommercialNoDerivatives 4.0 International (CC BY-NC-ND 4.0) licence. Full details of this licence are available at: https://creativecommons.org/licenses/by-nc-nd/4.0/

\section{LICENCE}

CC BY-NC-ND 4.0

\section{REPOSITORY RECORD}

Li, Hui, Hong Liu, Antonios Siganos, and Mingming Zhou. 2019. "Bank Regulation, Financial Crisis and the Announcement Effects of Seasoned Equity Offerings of US Commercial Banks". figshare. https://hdl.handle.net/2134/22065. 


\title{
Bank Regulation, Financial Crisis, and the Announcement Effects of Seasoned Equity Offerings of US Commercial Banks
}

\author{
Hui $\mathrm{Li}^{\mathrm{a}}$, Hong Liu ${ }^{\mathrm{b}}$, Antonios Siganos ${ }^{\mathrm{c}}$, Mingming Zhou ${ }^{\mathrm{d} 1}$
}

\begin{abstract}
This paper studies the differences in the announcement effects of seasoned equity offerings (SEOs) of commercial banks and non-banks, and explores the influence of bank regulation and the financial crisis on such differences. We find that abnormal stock returns on SEO announcements for US commercial banks are significantly higher than those of non-banks, consistent with the hypothesis that bank regulations reduce the likelihood that bank SEOs signal overpriced equity. The propensity score matching-based difference-in-difference analysis indicates that the differences in stock returns between banks and non-banks decreased during the 2007-09 financial crisis period and increased after the passage of the Dodd-Frank Act in 2010.

Keywords:

Seasoned Equity Offerings (SEOs); Announcement Stock Returns; Banks; Bank Regulation; Financial Crisis

JEL classification:

G01; G21; G14; G32

a Adam Smith Business School, University of Glasgow, Main Building, Glasgow, G12 8QQ, UK. Tel: +44 141330 4661. Email: h.li.1@ research.glasgow.ac.uk

b* Corresponding author: Adam Smith Business School, University of Glasgow, Main Building, Glasgow, G12 8QQ, UK. Tel: +44 141330 7688. Email: Hong.Liu@glasgow.ac.uk

c Adam Smith Business School, University of Glasgow, Main Building, Glasgow, G12 8QQ, UK. Tel: +44 141330 4809. Email: Antonios.Siganos@ glasgow.ac.uk

d College of Business, University of Colorado at Colorado Springs, U.S.A., Tel: +1 719255 5153. Email: mzhou@uccs.edu
\end{abstract}

\footnotetext{
${ }^{1}$ The authors would like to thank the editor Iftekhar Hasan and two anonymous referees, Chris Veld, Patrick Verwijmeren, Marie Dutordoir for helpful comments and suggestions.
} 


\section{Introduction}

The 2007-09 global financial crisis triggered extensive debate over the role of bank capital in preventing failure. Recent studies on bank capital adequacy find that capital has a significant impact on banks' systemic risk and banks' performance during financial crises (e.g., Gauthier et al., 2012; Acharya et al., 2012; Mehran and Thakor, 2011; Berger and Bouwman, 2013; Black and Hazelwood, 2013; Bessler and Kurmann, 2014). Seasoned equity offerings (SEOs) by banks are generally encouraged by regulators because they believe a higher level of capital for individual banks can help sustain a healthy financial system. The issuance of new equity by banks, however, gives mixed signals to market participants. New equity issuance may demonstrate a bank's commitment and willingness to comply with capital regulation and bank stability (Keeley, 1989), but it may also signal private information that a bank raises new equity capital in response to financial difficulties (Krishnan et al., 2010).

A large number of studies explore the announcement effects of SEOs by non-banks and find that SEO announcements are related with negative abnormal stock returns (e.g., Smith, 1986; Mikkelson and Partch, 1986; Barclay and Litzenberger, 1988; Hansen, 1989; Eckbo and Masulis, 1992; Corwin, 2003). ${ }^{2}$ This pattern is consistent with the signaling model of Myers and Majluf (1984) that an SEO announcement signals firm overvaluation. However, for banks, the information content of SEO announcements might not be straightforward given the banks' compliance of banking regulations. By examining the difference in the announcement effects between commercial banks' (banks hereafter) and non-banks' SEOs, we intend to discover the different nature of information content in the SEO announcement for banks from non-banks, and in particular, the implications of banking regulations in the event of bank SEOs. We extend our analysis by investigating how the 2007-09 global

\footnotetext{
${ }^{2}$ Veld et al. (2015) review and undertake meta-analysis on research studying the wealth effect on SEO announcements.
} 
financial crisis and the passage of the Dodd-Frank Wall Street Reform and Consumer Protection Act in 2010 may have influenced this difference. ${ }^{3}$

There are competing and even contradictory hypotheses regarding the difference in SEO announcements between banks and non-banks. On one hand, abnormal stock returns following bank SEO announcements are expected to be higher than those of non-banks. Keeley (1989), for example, argues that bank regulation reduces the information content that otherwise would be revealed by a security issuance (in general negative), and consequently stock announcement effects might be less negative for bank SEOs than those of non-banks. Regulation also limits the freedom and flexibility of bank managers to set the quantity and type of capital, and to time security offerings to take advantage of differential information between managers and stock market participants. ${ }^{4}$ Bank SEOs are therefore less likely to be considered overvalued by stock market participants than non-bank SEOs due to the lower information asymmetry between bank managers and investors.

In addition, investors might react more positively (i.e., less negatively) to bank SEOs relative to non-bank SEOs because higher capital ratio can reduce bank risk given the regulation constraints faced by banks. Polonchek et al. (1989) suggest that, unlike non-banks, banks are monitored by both the market and a regulator, and bank capital structure decisions are constrained by regulation. Regulators impose minimum capital ratios and restrictions on the type of securities that qualify for inclusion in these ratios. The capital requirement forces

\footnotetext{
${ }^{3}$ A number of studies have shown that non-bank firms tend to perform poorly in the long term after firms' SEO announcements. For example, Loughran and Ritter (1995) and Spiess and Affleck-Graves (1995) report that compared to non-equity issuers, equity issuers have lower profitability and, on average, have $7 \%$ lower returns annually, for the five years following each SEOs. Our study instead focuses on firms' wealth announcement effect at SEOs due to the problems highlighted with the estimation of long-term abnormal stock returns in the field. On the other hand, studying the long-term returns of bank SEOs versus non-bank SEOs could be an interesting topic for another research paper. This topic could be challenging too, as previous studies (e.g., Fama (1998)) report that long-term abnormal stock returns are highly sensitive to the expected stock return estimation model used. In addition, Brav et al. (2000) show that firms' long term abnormal stock returns after equity issuance are driven by small firms. Therefore, comparisons of long term stock returns between banks and nonbanks could potentially provide new and interesting contribution to the existing research, though it is beyond the scope of our study.

${ }^{4}$ Booth et al. (2002) also find that regulations reduce the impact of managerial decisions on shareholder wealth, and hence help to address the agency conflicts.
} 
banks to have more of their own capital at risk; they thus have less incentive to invest in highreturn but high-risk projects (Hellmann et al., 2001). Furlong and Keeley (1989) analyse the theoretical relation between capital regulation and bank asset risk and find that a higher bank capital ratio does not lead value-maximising banks to increase asset risk because more stringent capital requirements reduce a bank's gains from increasing the risk level of its asset portfolio. Assuming that overall capital regulation tends to reduce bank risk, investors are thus more inclined to build up confidence of bank SEOs than non-bank SEOs.

Finally, banks are perceived to benefit from the government's implicit too-big-to-fail (TBTF) policy. In principle, the government can always close a failing bank as soon as the bank becomes insolvent. In practice, however, the number of options available to regulators for handling bank insolvency problems decreases with the severity of the problem (e.g., Hoggarth et al., 2004; Barth et al., 2006; Kaufman, 2015). García-Palacios et al. (2014) also argue that in front of an imminent crisis, the promise of no interventions made by governments is barely credible. Recent empirical evidence shows that potential government implicit guarantee for banks has extensive implications on the market participants' perceptions. For example, it may lead to lower banks' cost of funding on expected government support (Antzoulatos and Tsoumas, 2014), positive stock market reactions upon the announcement of TARP injections (Elyasinai et al., 2014), and higher likelihood of having SEOs after receiving Capital Purchase program (CPP) funds (Khan and Vyas, 2015). With the perception that banks are less likely to fail under the TBTF policy compared to nonbanks, the market will be less sensitive to information revealed from SEO announcements, and hence the market reaction to the announcement of SEOs by banks than non-banks with the same characteristics is expected less severe.

On the other hand, there is a contrasting hypothesis suggesting that abnormal stock returns of bank SEO announcements may be lower than those of non-banks. Existing theories 
suggest that banks may be more opaque than non-banks because of the complex financial intermediation and the nature of the underlying assets (Haggard and Howe, 2012; Jones et al., 2012). ${ }^{5}$ The higher level of opacity may create difficulty in accurately evaluating bank SEOs (Krishnan et al., 2012), leading to a higher perception of overvaluation upon bank SEO announcements, and thus lower abnormal stock returns than for non-banks. ${ }^{6}$ Keeley (1989) also argues that an increase in equity reduces the option value of the deposit insurance guarantee because banks become less risky, and hence banks' SEO announcements may lead to a larger negative effect.

To test the validity of the competing hypotheses, we examine 375 SEO announcements of US banks and compare their cumulative announcement stock returns (CAR) to those of their non-bank counterparts from 1982 to 2012. Our main result supports the hypothesis that the announcement effect of banks is less negative than that of non-banks. The cumulative abnormal stock returns around the announcement window $(-1,1)$ for banks are -0.96 percent, 0.61 percent higher than that of non-banks. These results hold even after controlling for various firm-, issue- and market-specific variables. We further address the endogeneity concerns in the OLS regressions by adopting the propensity score matching (PSM) method to find the matched sample of non-banks for each bank and our PSM results confirm our main finding that the announcement effect is significantly higher for bank SEOs than non-bank SEOs.

We further explore whether the difference in stock returns between banks and nonbanks was influenced by the 2007-09 global financial crisis and the passage of the DoddFrank Wall Street Reform and Consumer Protection Act in 2010. Because banks were at the

\footnotetext{
${ }^{5}$ The empirical evidence of financial opacity compared to that of non-banks, however, is mixed, and there is no consensus among researchers (e.g., Morgan, 2002; Iannotta, 2006; Flannery et al., 2013; Dewally and Shao, 2013).

${ }^{6}$ Nier (2007) also finds that bank transparency reduces the chance of severe banking problems and enhances overall financial stability.
} 
center of the financial crisis, the announcement of SEOs at this time may have revealed significant negative information to the market. The difference in announcement effects between bank and non-bank SEOs may thus be reduced during the financial crisis period. On the other hand, the increased capital regulation and information disclosure requirements for banks after the passage of the Dodd-Frank Act in 2010 may have led to a decreased level of adverse selection costs and thus a positive impact on the announcement effects for bank SEOs. The difference in announcement effects between bank and non-bank SEOs is therefore expected to have increased after the passage of the Dodd-Frank Act. We provide propensity score matching-based pairwise difference-in-difference analysis to examine these two hypotheses. Our results confirm our expectations, showing that the difference in the announcement effects between banks and non-banks indeed decreased during the 2007-09 financial crisis period, but increased after the passage of the Dodd-Frank Act.

Our study contributes to the literature in several ways. We first contribute to the debate whether bank regulation could boost investor confidence and reduce firm equity issuing costs. Our result that banks have higher SEO announcement effect confirms Slovin et al.'s (1991) suggestion that banks are frequent equity issuers due to the low issuing costs. Our finding also complements Smith's (1986) result that utility firms, which operate in a highly regulated industry, also experience relatively higher SEO announcement effects than their less regulated counterparts. Our study offers credence to the theory that regulation could influence investors' perception of information asymmetry between investors and firm managers. To highlight the significance of regulation, we further focus on recent events, such as the financial crisis and the passage of the Dodd-Frank Act, to explore their impact on the difference between bank and non-bank SEO announcement stock returns. We find that issuing costs increase during the financial crisis period and decrease when government regulation tightens. 
Our paper also extends the work by Polonchek et al. (1989), who find that the mean abnormal stock returns of bank SEO announcements are higher than those of non-bank counterparts. The main limitation of Polonchek et al.'s (1989) study, however, is that it covers the period 1975-1984, before the adoption of Basel I in 1988 and the Federal Deposit Insurance Corporation Improvement Act (FDICIA) in 1991. These important regulation changes are thought to have had significant effects on the stock market behavior of bank SEOs. The 2007-09 financial crisis may also have changed investor perception of firm/bank SEO announcements. Their relatively small sample also suggests that their findings are not conclusive. For example, there are merely 41 equity event announcements in Polonchek et al.'s (1989) study, and the researchers themselves acknowledge that "the sample sizes involved in this study are necessarily small" (p. 449). Another recent study on UK rights issues between 1988 and 1998 is that by Iqbal (2008) who finds less negative stock market reactions in the rights offerings by financial firms compared with industrial firms. However, both studies' findings are based solely on the comparison of the mean values of the cumulated abnormal return (CAR) over the SEO announcement windows, and ignore the differences in other characteristics between banks and non-banks. These characteristics are important in determining the difference in CARs between banks and non-banks. For example, banks that issue SEOs are generally larger than non-banks, and the different stock market reactions to the announcement of SEOs may simply be caused by the difference in size between banks and non-banks.

Our paper also contributes to the strand of literature that explores determinants of the wealth announcement effect of bank SEOs. For example, Wansley and Dhillon (1989) find negative stock reaction from the issuance of common stock, the magnitude of which is similar to that found in the previous literature for utilities, and smaller than that of industrial firms. Keeley (1989) documents more negative announcement stock returns for involuntary 
bank stock issuances than voluntary ones during the 1975-1986 period, whereas Cornett and Tehranian (1994), on the contrary, find that involuntary equity issuance does not convey any signal of a firm's future prospects. Krishnan et al. (2010) find that both undercapitalized and well-capitalized banks have a significantly negative mean abnormal return around SEO announcements, indicating that investors do not perceive these two types of banks as economically different. Our result that the difference in CARs between banks and non-banks is significantly reduced over the financial crisis period indicates that it is more costly to issue equity for banks in bear markets. Consistent with the Basel III countercyclical capital buffer requirements (BIS, 2010), this result implies that banks should preserve sufficient capital when an economy are overheated in order to avoid costly SEOs when an economy falls into recession. .

Finally, our paper has implications for the recent growing interest in systemic risk literature since the 2007-09 global financial crisis. Capital adequacy of a bank has been documented to have a significant impact on its systemic risk and bank failures (Gauthier et al., 2012; Acharya et al., 2012; Arnold et al., 2012). In particular, Gauthier et al. (2012) show that macro prudential capital requirements are positively correlated to future capital raised by banks as well as future losses in equity value. Since equity issuance changes the capital ratio and the capital structure of a bank, it may have a significant influence on its systemic risk and may also have implications for the valuation and risk of its interconnected banks. Our finding that the differences in CARs between banks and non-banks are reduced after the passage of the Financial Services Modernization Act of 1999 may also imply that the deregulation in the US banking system may have contributed to fuel the increase of systemic risk in the last two decades.

The remainder of the paper is structured as follows: Section 2 describes the data and methodology, Section 3 presents our empirical results and Section 4 concludes. 


\section{Data and methodology}

We collect US seasoned equity offerings from the SDC database during the sample period from January 1, 1982, to December 31, 2012. We include all offers issued by firms listed on the NYSE and NASDAQ. We identify the sample using the database of the Centre for Research in Security Price (CRSP), with available firm account data from Compustat. We compare equity issuances between commercial banks (SIC codes 6000 to 6199) and nonbanks. From the latter group, we exclude issues from other industries that may face regulation restrictions such as utilities (SIC codes 4900 to 4999) and non-bank financial firms ${ }^{7}$ (SIC codes 6300-6499, 6200-6299 and 6500-6999). The dataset consists of 3,710 equity issues, out of which 375 are issued by banks and the remaining 3,388 are issued by non-banks. Panel A of Table 1 shows the number of equity announcements for banks and non-banks. The number of observations for banks and non-banks increased significantly after 2000, and the number of issuances reached its highest point in 2009-2010. The increase in the equity issuance of banks in recent years highlights the significance of new research in this field.

We measure the wealth announcement effect of equity offerings following a standard event study methodology (e.g., Brown and Warner, 1985). We estimate abnormal stock returns using the market model as follows:

$$
A R_{i, t}=R_{i, t}-\alpha_{i}-\beta_{i} R_{m, t}+\varepsilon_{i, t}
$$

where $R_{i, t}$ are the stock returns for equity issuance $i$ on day $t$, and $R_{m, t}$ is the corresponding daily stock market returns ( $\& \& \mathrm{P} 500$ ). The parameters $\alpha_{i}$ and $\beta_{i}$ are calculated over the estimation period (-250 and -10 days).

$$
\operatorname{CAR}(-1,1)_{i}=\alpha_{0}+\alpha_{1} \text { Bank dummy }+\alpha_{j} \sum \text { Control variables }+\varepsilon_{i}
$$

\footnotetext{
${ }^{7}$ Non-banks include insurance carriers, security and commodity brokers, dealers, exchanges, services, and real estate.
} 
Eq. (2) explores the relation between announcement stock returns after SEOs for banks compared to those for non-banks after controlling for a number of variables that may influence such relation. The bank dummy takes a value of 1 for banks, and 0 otherwise. The dependent variable $C A R(-1,1)_{i}$ is the cumulative abnormal stock returns for firm $i$ between days (-1 and 1) around each SEO announcement day (day 0). We use a three-day event window around each announcement in order to ensure that we capture the full price effect of the SEO announcement, and in untabulated results, we find that our conclusions are robust within alternative period estimations and announcement periods (e.g., between -2 and 2 days). Over the announcement period, selected stocks must have at least one non-missing daily return to be included in our sample.

We control at Eq. (2) for a number of conventionally used issue-specific, firm-specific and market-specific characteristics. ${ }^{8}$ To capture issue-specific characteristics, we control for secondary shares, which are offerings sold by existing shareholders. Secondary shares are typically associated with relatively low asymmetric information because issuers of secondary offers are older and have a larger book value of assets, sales, cash flow margins and proportions of tangible assets (Lee and Masulis, 2009; Brav and Gompers, 2003; Dor, 2003). We therefore expect a positive relation between secondary shares and SEO announcement effect. We also control for the indicator of Rule 415 shelf registration, which is a dummy variable of 1 for issuers under shelf registration rules who can decide to make a SEOs at any time within a two-year window and 0 otherwise. Issuers of Rule 415 can make the decision to go to the market and sell an issue within minutes, probably during favorable market conditions (Autore et al., 2008). ${ }^{9}$ There is therefore a positive expectation in the relation between Rule 415 and issuances' abnormal stock returns. Finally, we control for each

\footnotetext{
${ }^{8}$ In the robustness analysis section (Section 3.3), we include additional control variables.

${ }^{9}$ Before Rule 415, for selected companies, SEC regulations required a minimum delay of 48 hours between the decision to make the offering and the actual sale. For some companies, the delay could be several weeks to several months.
} 
issuance's proceeds/total assets to control for the magnitude of an equity issuance. According to Tan et al. (2002), large equity issuances are expected to be positively related with SEO announcement stock returns, since it is more likely that firms issue large equity when there are positive investment opportunities available.

To capture firm-specific characteristics, we use the following control variables. Share turnover is measured as a firm's trading volume divided by the number of outstanding shares, and firm size is measured by the natural logarithm of total assets. These variables are used to capture a firm's information asymmetry level. According to Corwin (2003), when small firms issue new equity, there is a higher level of uncertainty. We therefore expect a positive relation between share turnover and firm size with SEO announcement stock returns. We also control for the ratio of total equity over total assets. Firms with a lower equity level are considered more risky, facing higher expected costs of financial distress. We therefore expect a positive relation between equity level and SEO announcement effects. We also control for each firm's stock run-up over the interval period between -60 and -2 days prior to each SEO announcement. Lucas and McDonald (1991) argue that if a firm is undervalued, managers are more likely to delay issuing new equity to fund an investment project until good news about the firm is released. On the contrary, overvalued firms have incentives to issue equity immediately. Therefore, the announcement of an equity issued by a firm with high abnormal stock returns prior to the announcement is likely to have a more negative price reaction. We finally control for a firm's stock volatility, which is the standard deviation of daily stock returns in the interval period between -250 and -10 days prior to each issuance. Since firms with high volatility have a higher chance to face financial difficulties (Chang et al., 2004), a firm's volatility is expected to be negatively related to SEO announcement wealth effect.

Finally, we use stock market volatility and market run-up to control for market characteristics. Stock market volatility is used to capture macroeconomic uncertainty in the 
US market, which is defined as the annualized standard deviation of S\&P 500 daily returns in the year before the announced equity issuance. Market run-up is defined as the run-up of the S\&P 500 index in the interval period between -60 and -2 days prior to each announced equity issuance. According to Lewis et al. (2003), investor reactions are typically less negative following increases in stock market prices, and we therefore expect that SEO abnormal stock returns are positively related with market run-up.

Appendix 1 provides the definition of the variables used in this study. All firm- and macroeconomics-specific characteristics included in the regression analysis are measured at the fiscal year-end preceding the SEO announcement date.

\section{Empirical results}

\subsection{Univariate results}

Panel B of Table 1 provides the summary statistics of the key variables used in this study for banks and non-bank firms. We find that the equity offerings' CAR over the window $(-1,1)$ for US banks is, on average, -0.98 percent, which is 0.61 percent higher than that of non-banks. The difference in stock returns between banks and non-banks is statistically significant at the $1 \%$ level. These results are consistent with Poloncheck et al. (1989) and Wansley and Dhillon (1989), who find that bank-issued equity has a less negative announcement effect than that of non-banks, although our findings are driven by a lengthier recent period with a significantly larger number of bank equity issuance announcements.

We further show the statistics of the control variables. We find that secondary shares issued by banks are significantly larger than those issued by non-banks. The trading frequency of bank-issued equity is less than that of non-bank-issued equity; the share turnover is significantly lower. We find that banks are significantly larger than non-banks, the average total assets being $\$ 32.58$ and $\$ 2.16$ billion, respectively. This difference is not 
surprising, given that most commercial banks in our sample are listed at the Bank Holding Company (BHC) level and tend to be large in size. The proceeds to assets ratio of banks is, however, significantly lower than that of non-banks (3.07\% and $26.39 \%$, respectively). The smaller proceeds ratio may to some extent reflect the significantly larger size of banks. We also observe a significantly lower equity/assets ratio for banks. Nevertheless, the $11.85 \%$ equity ratio is significantly higher than the government-required level, and it may indicate the safe conditions of banks that issued equity during the sample period. We further notice that the stock run-up of banks $(9.39 \%)$ is significantly lower than that of non-banks $(14.08 \%)$. Banks may face fewer financial constraints than their non-bank counterparts, and hence, bank managers may tend to issue equity when they need it, whereas managers of non-banks may have to consider the timing of the issuance to reduce the issuance cost. We find that banks have less operational risk than non-banks because banks' stock volatility is significantly lower. In line with Duca et al. (2012), the volatility of banks is higher than that of non-banks, indicating that banks face a higher level of debt-related financing costs. The market run-up for banks is also significantly higher.

Figure 1 reports the trend analysis of announcement stock returns over time for banks and non-banks. Although we cannot exactly match the same period used by Poloncheck et al. (1989), ${ }^{10}$ we find that banks have a less negative SEO announcement effect relative to nonbanks in the early 1980s. Interestingly, the difference in CARs between banks and non-banks increased after 1994. The increased competition by allowing banks to enter new markets after the passage of the Riegle-Neal Interstate Banking and Branching Efficiency Act (Stiroh and Strahan, 2003) encouraged banks to voluntarily disclose particularly unfavourable information to deter new entry (Darrough and Stoughton, 1990), and/or disclose more quality

\footnotetext{
${ }^{10}$ Poloncheck et al. (1989) use the period between 1975 and 1984, while our data commence in January 1982.
} 
information on the risks involved to gain reputation from the perspective of customers and potential investors (Barakat and Hussainey, 2013).

This trend, however, is reversed after the passage of the Financial Services Modernization Act of 1999, after which we observe that the difference in CARs between banks and non-banks is reduced. The repeal of the Glass-Steagall Act encouraged banks to engage in more diversified business, and the consequent M\&A wave among banks led to higher industry concentration and reduced competition (Chronopoulos et al., 2015). We also find a significant increase of bank CARs relative to non-banks after 2010, when the DoddFrank Wall Street Reform and Consumer Protection Act was passed. It introduced more stringent regulation on capital adequacy and information disclosure as well as consumer protection, which led to a decreased level of adverse selection costs for financial institutions' security sales. Overall, Figure 1 demonstrates that while SEOs by banks signal less negative information compared to non-banks, the strength of this signal seems to be influenced by the stringency of different bank regulations over time.

\subsection{Multivariate results}

In this section, we test whether the less negative announcement effects of bank SEOs than non-bank SEOs can be explained by firm-, market- and issue-specific characteristics. We run Eq. (2) using OLS with White-corrected standard errors (White, 1980). The dependent variable is the cumulative stock returns around each SEO announcement (from -1 to 1 day). In line with the univariate results, column (1) of the multivariate results in Table 2 shows that the bank dummy is significantly positive at the $5 \%$ level after controlling for a number of variables, with a parameter coefficient equal to 0.617. This result indicates that banks' announcement stock returns of equity issuance are 0.617 percent higher than counterpart stock returns experienced by non-banks. This result supports the information hypothesis that 
bank regulators' monitoring and disclosure requirements lower the information asymmetry between bank managers and investors, therefore reducing the adverse selection problem and giving investors more confidence. ${ }^{11}$

The signs of the parameter coefficients for the control variables and the significance levels are to a large extent in line with our expectations. For example, in line with Autore et al. (2008), we find that issuers of equity under Rule 415 experience a positive stock reaction from the offering, because shelf-registered equity has lower underwriting fees, consistent with a dominant underwriter competition effect. In line with Lee and Masulis (2009), we find that secondary shares have a significant, positive relation with the equity offering effect, because issuers of secondary shares face less information asymmetry and adverse selection problems with investors. In line with Lucas and McDonald (1991), larger pre-announcement stock price run-ups are associated with larger stock price drops following the offering announcement. Because overvalued firms may have incentives to issue immediately, equity issuances will occur after a period of positive abnormal stock returns to the firm. We also find that stock volatility has a negative effect on the equity announcement effect, which is consistent with Chang et al. (2004). We also observe that market run-ups tend to be positively associated with the stock price reaction to equity announcements. This finding is consistent with Lewis et al. (2003), who find that investor reactions are less negative following increases in stock market prices.

\subsection{Robustness analyses}

We include a number of additional control variables to check the robustness of our previous findings. In column (2) of Table 2, we add a dummy variable '2007-09 financial

\footnotetext{
${ }^{11}$ This result is consistent if we control for year fixed effects. We did not include year fixed effects because we need to include the 2007-09 financial crisis dummy variable to examine the impact of the financial crisis on the difference in SEO announcement stock returns between bank and non-bank.
} 
crisis', which is equal to 1 if the equity was issued from 2007 to 2009 , and 0 otherwise, to control for the effect of the 2007-09 financial crisis. We find that the parameter coefficient for the 2007-09 financial crisis dummy is significantly negative, indicating that during the crisis, stock returns after the issuance of bank equity were more negative than in the rest of the sample period. More importantly, the parameter coefficient for bank dummy remains significantly positive after controlling for the 2007-09 financial crisis.

In column (3) of Table 2, we include the firm commitment dummy variable, which equals 1 for equity issued as a firm commitment (the entire issue is sold directly to the underwriter), and 0 otherwise. Previous research suggests that the issuance of equity with firm commitment has lower direct issue costs (underpricing and investment bank compensation) than the alternative use of best efforts offering methods (Dunbar, 1998). In a firm commitment, the issuing firm is assured of the dollar value of the proceeds of the offerings. In the case that the share price of the issuing firm drops, the new shares cannot be issued at their issue price, and the underwriter bears an unexpected loss. We find that equity issued by the firm commitment method is slightly insignificant ( $p$-value $=0.110$ ) in relation to the announcement effect of the equity offering. Our main result, though, holds, with bankissued equity having higher abnormal stock returns than equity issued by non-banks after controlling for firm commitment.

In column (4) of Table 2, we include a dummy variable for capital expenditure, which equals 1 if the intended use of the proceeds is for capital expenditure, and 0 otherwise. McConnel and Muscarella (1985) argue that if managers follow the market value maximization rule, an announcement of an unexpected increase in capital expenditure should have a positive effect on the market value of the firm, and vice versa. The positive revaluation associated with unexpected capital expenditure increases because the market immediately capitalizes on the incremental positive NPV associated with the unexpected 
projects to be undertaken by the firm. We find that our main results hold, with banks having 0.647 per cent higher abnormal stock returns after controlling for capital expenditure, although we do not find that the use of proceeds has a significant relation with the equity offering effect.

In column (5) of Table 2, we add inverse elasticity to the main regression to measure the price pressure. In Gao and Ritter's (2010) model, the demand elasticity for a stock is determined by an order flow inverse to demand elasticity. Inverse elasticity is the natural log transformation of the absolute value of daily raw stock returns divided by daily turnover, averaged over -250 trading days before the announcement date. The daily order flow inverse price elasticity on day $t$ is defined as the ratio between the absolute value of a stock's raw returns and its share turnover. If the stock is listed on NASDAQ, we apply various adjustments to the trading volume. ${ }^{12}$ To reduce the influence of extreme values, we use a natural log transformation. A large inverse elasticity reflects a large change in price if there is a demand or supply shock, which implies an inelastic demand curve. If a firm issues new equity, a more inelastic demand leads to a greater reduction in the stock price. Therefore, we expect a negative relation between stock inverse elasticity and the stock reaction to the equity offering. We find that the parameter coefficient for inverse elasticity is insignificant, but, more importantly, the parameter coefficient of bank remains significantly positive with the inclusion of the inverse elasticity variable.

\footnotetext{
${ }^{12}$ In line with Gao and Ritter (2010), we adjust trading volume for NASDAQ firms. On February 1, 2001, a 'riskless principal' rule went into effect, and according to the director of research of NASDAQ and Frank Hathaway, the chief economist of NASDAQ, this resulted in an approximately $10 \%$ reduction in reported volume. Thus, for February 1, 2001, to December 31, 2001, we divide NASDAQ's firm trading volume by 1.8. In 2002, securities firms began to charge institutional investors commissions on NASDAQ trades rather than following the prior practice of merely marking up or down the net price, resulting in a further reduction in the reported volume of approximately 10\%. Thus, for 2002 and 2003, we divide the NASDAQ volume by 1.6. No further adjustment in trading volume for NASDAQ firms is undertaken since 2004.
} 
In column (6) of Table 2, we add arbitrage risk instead of inverse elasticity to measure the price pressure. Arbitrage risk is the variance of the market model OLS regression residuals estimated over the -250 trading days (Wurgler and Zhuravskaya, 2002). In Wurgler and Zhuravskaya's (2002) model, the demand elasticity for a stock is determined by the arbitrage risk. Arbitrageurs keep the demand curve flat if the asset has perfect substitutes and the arbitrage risk is 0 . By contrast, if the asset does not have perfect substitutes, the demand curve is downward sloping because the arbitrage risk is nonzero, and arbitrageurs are riskaverse. As the arbitrage risk becomes greater, the demand curve becomes more elastic. Wurgler and Zhuravskaya (2002) show that there is a positive relation between arbitrage risk and stock returns on the announcement day of S\&P 500 additions, which suggests that stocks with greater arbitrage risk have less elastic demand. Gao and Ritter (2010) find comparable results of arbitrage risk. If a firm issues new equity, a more inelastic demand leads to a greater reduction in stock price. We therefore expect a negative relation between stock arbitrage risk and stock reaction to the equity offering. Once again, we find that the parameter coefficient for arbitrage risk is insignificant, but the abnormal higher stock returns for banks than for non-banks are still present.

\subsection{Matched sample results}

In this section, we construct a propensity-score matched sample (PSM) by identifying for each bank a non-bank with similar characteristics. To accomplish this, we first use the propensity score estimations in the probit model using a selection of firm-, issue- and marketspecific variables, which may help to define the differences between banks and non-banks. Because banks are on average significantly larger than non-banks, matching a bank with a non-bank of a similar size may be biased. For example, a $\$ 1$ billion sized bank may be perceived as small, whereas a $\$ 1$ billion sized non-bank may be perceived as large. Similarly, 
because banks are on average more leveraged than non-banks, matching a bank with a nonbank with a similar leverage ratio may also create bias in the matching. Hence, we classify size into deciles within banks and non-banks separately, and restrict the matching process in the same deciles. We also match the non-banks in the same decile for the equity-to-assets ratio as the corresponding banks. Finally, we restrict the matched non-bank sample from the same year to avoid possible biases from time effects. These restrictions can lead to large reductions in bias, a design that is analogous to blocking in a randomized experiment. We then proceed to find, for each bank, the non-bank with the closest (lowest absolute value) difference in the probability estimate, and we do so with replacement.

We estimate the mean difference in CARs between banks and matched non-banks. Panel A of Table 3 reports the probit results, and Panel B, the PSM results. Panel A shows that, compared to non-banks, when issuing SEOs, banks are more likely to issue a lower ratio of proceeds relative to total assets, and that the market volatility and market run-up are both higher, less likely to issue secondary issues, and more likely to issue shelf registered issues. Panel B shows that the difference in CAR between banks and matched non-banks is $1.53 \%$, which is significant at the $1 \%$ level, supporting our prior conclusion that banks have higher announcement stock returns following SEOs than non-banks.

\subsection{The impact of the 2007-09 financial crisis and the Dodd-Frank Act}

In this section, we conduct difference-in-difference analysis to examine the impact of the 2007-09 global financial crisis and the passage of the Dodd-Frank Act in 2010 on the difference in the announcement effects between banks and non-banks. The difference in the SEO announcement effects between banks and non-banks may be different in this period from normal periods in two contrasting ways. On the one hand, the SEOs in a financial crisis period, when the market price is low, indicate that the bank is less likely to time the market to 
issue equity but is rather issuing for true business purposes, including meeting government requirements. Investors are therefore less likely to hypothesize that bank equity issuance signals information that the bank is overvalued during the financial crisis period compared to normal periods. The implication is then that the difference in the announcement effects of SEOs between banks and non-banks will increase in the financial crisis period. However, the same perception that non-banks may also be less likely to time the market during financial crisis may cancel out the effects, leaving the difference unchanged during the financial crisis. On the other hand, bank SEOs during the financial crisis period may signal to market participants that the bank's condition has deteriorated, and the market may respond with even more negative announcement effects than in normal periods. This effect may be stronger for banks than non-banks because banks in general suffered more than non-banks during the 2007-09 financial crisis. The implication of this argument is that the difference between banks and non-banks following SEO announcements is lower during the financial crisis than the normal period.

We take the difference in CARs between banks and matched non-banks using the propensity score matching method described in Section 3.4. We then employ the differencein-difference (DiD) estimator to examine whether this difference differs between the 2007-09 financial crisis and the normal period. Table 4 reports the results of two specifications. In the first specification, we include the whole sample period and examine the difference between the 2007-09 financial crisis in relation to the remaining period. In the second specification, we include only the time after 2003 to consider the most recent boom and crisis cycle. The dependent variable is the difference in CARs between banks and matched non-banks. 200709 financial crisis is an indicator variable, which equals 1 for the years from 2007 to 2009 , and 0 otherwise. We find that the parameter coefficient of the 2007-2009 financial crisis variable is significantly negative (-2.586), indicating that the difference in CARs between 
banks and non-banks decreases during the 2007-09 financial crisis period. This result confirms our second hypothesis that bank SEOs during the financial crisis seem to have sent a signal to market participants that the banks' condition had deteriorated, and therefore investors reacted negatively to banks' SEO announcements. ${ }^{13}$

In addition, we explore the impact of the passage of the Dodd-Frank Wall Street Reform and Consumer Protection Act in 2010 on the difference in SEO announcement effects between banks and non-banks. The passage of the Dodd-Frank Act introduced more stringent regulation on capital adequacy and information disclosure, as well as consumer protection, which may have led to a decreased level of adverse selection costs for financial institutions' security sales. The hypothesis is that the reduced information asymmetry may have increased the announcement effects for bank SEOs, which would result in an increase in the difference in CARs between banks and non-banks. We test this hypothesis by examining the difference in CARs between banks and matched non-bank samples three years before and after 2010. Dodd-Frank is an indicator variable which equals 1 for the time period from 2010 to 2012, and 0 otherwise. Column (3) of Table 4 shows that the parameter coefficient of the Dodd-Frank Act is significantly positive (5.962 and significant at the 5\% level), showing that the reduced information asymmetry increased the announcement effects for bank SEOs.

\section{Conclusion}

This study examines whether the announcement effect of seasoned equity offerings (SEOs) by commercial banks differs from that of non-banks. We find that banks experience less negative announcement stock returns than non-banks when issuing equity. The difference

\footnotetext{
${ }^{13}$ Note that we exclude control variables in this DiD analysis, since they have already been considered in the propensity score matching analysis. In untabulated results, we include all control variables and find that all of them are insignificant, while our main conclusion holds regarding the main parameter coefficient on the financial crisis.
} 
in the cumulative stock returns associated with equity offered by banks is 0.61 percent higher than that issued by non-banks. Bank regulations limit bank behavior, demand sufficient capital, and provide support under the implicit too-big-to-fail policy. Market participants are therefore less likely to associate bank SEO announcements with bank overvaluation as they do for the non-bank SEOs. Our difference-in-difference analysis further shows that the difference in abnormal stock returns between banks and non-banks decreases during the 2007-09 global financial crisis period and increases after the passage of the Dodd-Frank Act in 2010. We should, however, be cautious to interpret this last result because the impact of the Dodd-Frank Act also clashes with the implementation of Basel III during the same period. Our results overall highlight the significance of recent regulation on the wealth announcement effect of bank SEOs.

Our paper shed light on the debate over the impact of bank regulation on systemic risk and bank behavior. Our evidence that bank regulation may lead to lower information asymmetry between banks and investors by restricting banks' risk taking and encouraging information disclosure has extensive implications for policy makers. On the other hand, although banks may face high level of compliance cost, the reduced information asymmetry may also help them to achieve lower borrowing cost in the financial market. 


\section{References}

Acharya, V., Engle, R., and Richardson, M., 2012. Capital shortfall: A new approach to ranking and regulating systemic risks. The American Economic Review 102, 59-64.

Antzoulatos, A.A., and Tsoumas, C., 2014. Institutions, moral hazard and expected government support of banks. Journal of Financial Stability 15, 161-171.

Arnold, B., Borio, C., Ellis, L., and Moshirian, F., 2012. Systemic risk, macroprudential policy frameworks, monitoring financial systems and the evolution of capital adequacy. Journal of Banking \& Finance 36, 3125-3132.

Autore, D., Kumar, R., and Shome, D., 2008. The revival of shelf-registered corporate equity offerings. Journal of Corporate Finance 14, 32-50.

Bank for International Settlements, 2010, Basel III: A global regulatory framework for more resilient banks and banking systems. Basel Committee on Banking Supervision.

Barakat, A., and Hussainey, K., 2013. Bank governance, regulation, supervision, and risk reporting: Evidence from operational risk disclosures in European banks. International Review of Financial Analysis 30, 254-273.

Barclay, M.J., and Litzenberger, R.H., 1988. Announcement effects of newequity issues and the use of intraday price data. Journal of Financial Economics 21, 213-232.

Barth, J.R., Caprio, G. Jr., and Levine, R., 2006. Rethinking bank regulation: Till angels govern. Cambridge University Press.

Berger, A.N., and Bouwman, C.H.S., 2013. How does capital affect bank performance during financial crises. Journal of Financial Economics 109, 146-176.

Bessler, W., and Kurmann, P., 2014. Bank risk factors and changing risk exposures: Capital market evidence before and during the financial crisis. Journal of Financial Stability 13, 151166.

Black, L.K., and Hazelwood, L.N., 2013. The effect of TARP on bank risk-taking. Journal of Financial Stability 9, 790-803.

Booth, J.R., Cornett, M.M., and Tehranian, H., 2002. Boards of directors, ownership, and regulation. Journal of Banking \& Finance 26, 1973-1996.

Brav, A., Geczy, C., and Gompers, P., 2000. Is the abnormal returns following equity issuance anomalous?. Journal of Financial Economics 56, 209-249.

Brav, A., and Gompers, P.A., 2003. The role of lockups in initial public offerings. Review of Financial Studies 16, 1-29.

Brown, S.J., and Warner, J.B., 1985. Using daily stock returns: The case of event studies. Journal of Financial Economics 14, 3-31.

Chang, S-C., Chen, S-S., and Liu, Y., 2004. Why firms use convertibles: A further test of the sequential-financing hypothesis. Journal of Banking \& Finance 28, 1163-1183.

Chronopoulos, D.K., Liu, H., McMillan, F.J., and Wilson, J.O.S., 2015. The dynamics of US bank profitability. The European Journal of Finance 21, 426-443. 
Cornett, M.M., and Tehranian, H., 1994. An examination of voluntary versus involuntary security issuances by commercial banks: The impact of capital regulations on common stock returns. Journal of Financial Economics 35, 99-122.

Corwin, S.A., 2003. The determinants of underpricing for seasoned equity offers. Journal of Finance 5, 2249-2279.

Darrough, M.N., and Stoughton, N.M., 1990. Financial disclosure policy in an entry game. Journal of Accounting and Economics 12, 219-243.

Dewally, M., and Shao, Y., 2013. Financial derivatives, opacity, and crash risk: Evidence from large US banks. Journal of Financial Stability 9, 565-577.

Dor, A.B., 2003. The determinants of insiders' selling at initial public offerings: an empirical analysis. Unpublished Working Paper, Northwestern University, Evanston, IL.

Duca, E., Dutordoir, M., Veld, C., and Verwijmeren, P., 2012. Why are convertible bond announcements associated with increasingly negative issuer stock returns? An arbitragebased explanation. Journal of Banking \& Finance 36, 2884-2899.

Dunbar, C.G., 1998. The choice between firm-commitment and best-efforts offering methods in IPOs: the effect of unsuccessful offers. Journal of Financial Intermediation 7, 60-90.

Eckbo, B.E., and Masulis, R.W., 1992. Adverse selection and the rights offer paradox. Journal of Financial Economics 32, 293-332.

Elyasiani, E., Mester, L.J., and Pagano, M.S., 2014. Large capital infusions, investor reactions, and the return and risk-performance of financial institutions over the business cycle. Journal of Financial Stability 11, 62-81.

Fama, E., 1998. Market efficiency, long-term returns, and behavioral finance. Journal of Financial Economics 49, 283-306.

Flannery, M.J., Kwan, S.H., and Nimalendran, M., 2013. The 2007-09 Financial Crisis and Bank Opaqueness. Journal of Financial Intermediation 22, 55-84.

Furlong, F.T., and Keeley, M.C., 1989. Capital regulation and bank risk-taking: A note. Journal of Banking \& Finance 13, 883-891.

Gao, X., and Ritter, J.R., 2010. The marketing of seasoned equity offerings. Journal of Financial Economics 97, 33-52.

García-Palacios, J.H., Hasman, A., and Samartín, M., 2014. Banking crises and government intervention, Journal of Financial Stability 15, 32-42.

Gauthier, C., Lehar, A., and Souissi, M., 2012. Macroprudential capital requirements and systemic risk. Journal of Financial Intermediation 21, 594-618.

Haggard, K.S., and Howe, J.S., 2012. Are banks opaque? International Review of Accounting Banking, and Finance 4, 51-72.

Hansen, R.S., 1989. The demise of the rights issue. Review of Financial Studies 1, 289-309.

Hellmann, T.F., Murdock, K.C., and Stiglitz, J.E., 2001. Liberalization, moral hazard in banking, and prudential regulation: are capital requirements enough? The American Economic Review 90, 147-165. 
Hoggarth, G., Reidhill, J., and Sinclair, P., 2004. On the resolution of banking crises: Theory and evidence. London: Bank of England.

Iannotta, G., 2006. Testing for opaqueness in the European banking industry: evidence from bond credit ratings. Journal of Financial Services Research 30, 287-309.

Iqbal, A., 2008. The importance of the sequence in UK rights issues. Journal of Business Finance \& Accounting 35, 150-176.

Jones, J.S., Lee, W.Y., and Yeager, T.J., 2012. Opaque banks, price discovery, and financial instability. Journal of Financial Intermediation 21, 383-408.

Kaufman, G.G., 2015. Too big to fail in banking: What does it mean? Journal of Financial Stability 13, 214-223.

Keeley, M., 1989. The stock price effects of bank holding company security issuance. Economic Review, Federal Reserve Bank of San Francisco 1, 3-19.

Khan, M., and Vyas, D., 2015. The capital purchase program and subsequent bank SEOs. Journal of Financial Stability 18, 91-105.

Krishnan, C.N.V., Ergungor, O.E., Laux, P.A., Singh, A.K., and Zebedee, A.A., 2010. Examining bank SEOs: Are offers made by undercapitalized banks different? Journal of Financial Intermediation 19, 207-234.

Lee, G., and Masulis, R.W., 2009. Seasoned equity offerings: quality of accounting information and expected flotation costs. Journal of Financial Economics 92, 443-469.

Lewis, C.M., Rogalski, R.J., and Seward, J.K., 2003. Industry conditions, growth opportunities and market reactions to convertible debt financing decisions. Journal of Banking \& Finance 27, 153-181.

Loughran, T., and Ritter, J., 1995. The new issues puzzle. Journal of Finance 50, 23-51.

Lucas, D., and McDonald, R., 1991. Equity issues and stock and price dynamics. Journal of Finance 45, 1019-1043.

McConnell, J.J., and Muscarella, C.J., 1985. Corporate capital expenditure decisions and the market value of the firm. Journal of Financial Economics 14, 399-422.

Mehran, H., and Thakor, A., 2011. Bank capital and value in the cross-section. Review of Financial Studies 4, 1019-1067.

Mikkelson, W.H., and Partch, M.M., 1986. Valuation effects of security offerings and the issuance process. Journal of Financial Economics 15, 30-60.

Morgan, D.P., 2002. Rating banks: risk and uncertainty in an opaque industry. The American Economic Review 92, 874-888.

Myers S.C., and Majluf, N.S., 1984. Corporate financing and investment decisions when firms have information that investors do not have. Journal of Financial Economics 13, 187221.

Nier, E.W., 2005. Bank stability and transparency. Journal of Financial Stability 1, 342-354.

Polonchek, J., Slovin, M.B., and Sushka, M.E., 1989. Valuation effects of commercial bank security offerings: A test for information hypothesis. Journal of Banking \& Finance 3, 443461. 
Slovin, M.B., Sushka, M.E., and Polonchek, J.A., 1991. The information content of multiple seasoned common stock offerings by bank holding companies. Journal of Banking \& Finance 15, 633-646.

Smith, G., 1986. Investment banking and the capital acquisition process. Journal of Financial Economics 15, 3-29.

Spiess, D., and Affleck-Graves, J., 1995. Underperformance in long-run stock returns following seasoned equity offerings. Journal of Financial Economics 38, 243-267.

Stiroh, K.J., and Strahan, P.E., 2003. Competitive dynamics of deregulation: Evidence from U.S. banking. Journal of Money, Credit and Banking 35, 801-828.

Tan, R., Chng, P., and Tong, Y., 2002. Private placements and rights issues in Singapore. Pacific-Basin Finance Journal 10, 29-54.

Veld, C., Verwijmeren, P., and Zabolotnyuk, Y., 2015. Wealth effects of seasoned equity offerings: A meta analysis. Working paper.

Wansley, J.W., and Dhillon, U.S., 1989. Determinants of valuation effects for security offerings of commercial bank holding companies. Journal of Financial Research 12, 217-234.

White, H., 1980. A heteroskedasticity-consistent covariance matrix estimator and a direct test for heteroskedasticity. Econometrica 48, 817-838.

Wurgler, J., and Zhuravskaya, E., 2002. Does arbitrage flatten demand curves for stocks? Journal of Business 75, 582-608. 


\section{Table 1}

\section{Summary statistics}

This table shows the summary statistics. Panel A reports the number of observations for both banks and nonbanks for each year across the sample period. Panel B provides the descriptive statistics and t-test for the cumulative abnormal stock returns (CARs) and firm-specific, issue-specific and macroeconomic variables for banks and non-bank firms over the sample period. Variables are defined in Appendix 1. Student's t-test is used to examine the differences in the mean value of CAR and each firm-, issue-, and market-specific characteristic between banks and non-bank firms. Total assets are in billions of US dollars. N denotes the number of observations. *,** and $* * *$ represent the $10 \%, 5 \%$ and $1 \%$ significance levels, respectively.

Panel A: Yearly number of observations

\begin{tabular}{cccccc}
\hline Year & Banks & Non-banks & Year & Banks & Non-banks \\
\hline 1982 & 3 & 61 & 1998 & 16 & 80 \\
1983 & 3 & 150 & 1999 & 4 & 84 \\
1984 & 3 & 28 & 2000 & 6 & 87 \\
1985 & 3 & 37 & 2001 & 17 & 228 \\
1986 & 4 & 53 & 2002 & 12 & 211 \\
1987 & 4 & 52 & 2003 & 21 & 231 \\
1988 & 2 & 30 & 2004 & 20 & 275 \\
1989 & 0 & 32 & 2005 & 16 & 189 \\
1990 & 1 & 36 & 2006 & 15 & 176 \\
1991 & 9 & 109 & 2007 & 10 & 121 \\
1992 & 8 & 68 & 2008 & 13 & 71 \\
1993 & 14 & 121 & 2009 & 59 & 138 \\
1994 & 2 & 99 & 2010 & 45 & 85 \\
1995 & 10 & 134 & 2011 & 25 & 61 \\
1996 & 12 & 145 & 2012 & 10 & 65 \\
1997 & 8 & 131 & Total & 375 & 3388 \\
\hline
\end{tabular}




\begin{tabular}{|c|c|c|c|c|c|c|c|c|c|c|c|c|c|c|}
\hline \multirow[b]{2}{*}{ Variable } & \multicolumn{6}{|c|}{ Banks } & \multicolumn{6}{|c|}{ Non-banks } & \multirow{2}{*}{$\begin{array}{c}\text { Mean of } \\
\text { Panel } 1 \text { vs } \\
\text { mean of } \\
\text { Panel } 2\end{array}$} & \multirow{2}{*}{$\begin{array}{c}\text { Median o } \\
\text { Panel } 1 \mathrm{vs} \\
\text { median of } \\
\text { Panel } 2 \\
\end{array}$} \\
\hline & $\mathrm{N}$ & Mean & Std.dev. & Median & Min & Max & $\mathrm{N}$ & Mean & Std.dev. & Median & Min & Max & & \\
\hline CAR, $\%$ & 375 & -0.98 & 4.45 & -0.71 & -12.77 & 9.67 & 3388 & -1.59 & 4.86 & -1.62 & -13.35 & 9.71 & $0.61 * * *$ & 0.90 \\
\hline Secondary & 375 & 0.30 & 0.46 & 0.00 & 0.00 & 1.00 & 3388 & 0.51 & 0.50 & 1.00 & 0.00 & 1.00 & $-0.21 * * *$ & -1.00 \\
\hline Rule 415 shelf & 375 & 0.31 & 0.46 & 0.00 & 0.00 & 1.00 & 3388 & 0.36 & 0.48 & 0.00 & 0.00 & 1.00 & $-0.06 * *$ & 0.00 \\
\hline Share turnover & 375 & 4.90 & 8.95 & 1.40 & 0.00 & 50.19 & 3388 & 6.62 & 10.74 & 2.06 & 0.00 & 50.19 & $-1.73 * * *$ & -0.65 \\
\hline Total assets & 375 & 32.58 & 142.04 & 3.47 & 0.03 & 1309.6 & 3388 & 2.16 & 19.76 & 0.26 & 0.00 & 797.77 & $1.15 * * *$ & 0.09 \\
\hline Proceeds/total assets & 375 & 3.07 & 7.82 & 1.18 & 0.10 & 93.08 & 3388 & 26.39 & 32.26 & 15.31 & 0.10 & 173.20 & $-23.32 * * *$ & -14.13 \\
\hline Equity/total assets & 375 & 11.78 & 9.65 & 9.61 & -2.16 & 73.48 & 3388 & 55.39 & 25.31 & 56.66 & -35.11 & 93.96 & $-43.61 * * *$ & -47.05 \\
\hline Stock run-up & 375 & 9.39 & 22.33 & 6.74 & -41.23 & 92.17 & 3388 & 14.08 & 26.42 & 11.45 & -41.23 & 92.17 & $-4.69 * * *$ & -4.71 \\
\hline Stock volatility & 375 & 52.08 & 34.41 & 40.45 & 15.95 & 164.60 & 3388 & 58.05 & 28.75 & 52.20 & 15.95 & 164.60 & $-5.97 * * *$ & -11.75 \\
\hline Market volatility & 375 & 19.01 & 9.95 & 16.78 & 7.75 & 45.64 & 3388 & 16.04 & 7.43 & 13.88 & 7.75 & 45.64 & $2.97 * * *$ & 2.90 \\
\hline Market run-up & 375 & 4.15 & 6.91 & 4.63 & -12.72 & 16.64 & 3388 & 3.48 & 6.30 & 3.74 & -12.72 & 16.64 & $0.67 * *$ & 0.89 \\
\hline 2007-09 financial crisis & 375 & 0.22 & 0.41 & 0.00 & 0.00 & 1.00 & 3388 & 0.10 & 0.30 & 0.00 & 0.00 & 1.00 & $0.12 * * *$ & 0.00 \\
\hline Firm commitment & 375 & 0.57 & 0.50 & 1.00 & 0.00 & 1.00 & 3388 & 0.52 & 0.50 & 1.00 & 0.00 & 1.00 & $0.05 * * *$ & 0.00 \\
\hline Capital expenditure & 375 & 0.22 & 0.42 & 0.00 & 0.00 & 1.00 & 3388 & 0.14 & 0.35 & 0.00 & 0.00 & 1.00 & $0.08 * * *$ & 0.00 \\
\hline Inverse elasticity & 375 & 1.33 & 1.53 & 1.16 & -1.65 & 5.44 & 3334 & 1.18 & 1.71 & 1.00 & -1.65 & 5.44 & $0.16 * * *$ & 0.16 \\
\hline Arbitrage risk & 373 & 11.00 & 1.06 & 10.85 & 8.99 & 13.87 & 3387 & 11.44 & 0.95 & 11.46 & 8.99 & 13.87 & $-0.44 * * *$ & -0.61 \\
\hline Bid-ask spread & 347 & 1.80 & 2.10 & 1.17 & 0.06 & 9.59 & 3123 & 2.00 & 2.15 & 1.29 & 0.06 & 9.59 & $-0.19 *$ & -0.12 \\
\hline
\end{tabular}




\section{Table 2}

SEO announcement stock returns for banks

This table shows the results of the OLS regression analysis of the difference in cumulative abnormal stock returns of SEOs between banks and non-banks, controlling for firm-specific, issue-specific and market-specific measures. The interval period used is between -250 to -10 days (day $0=$ SEO announcement) for the estimation. The dependent variable is cumulative abnormal stock returns (\%) over the interval period (-1, 1 days), as calculated using the market model. Bank is a dummy variable for commercial banks. All other explanatory variables are defined in Appendix 1. Pvalues are estimated using White's (1980) heteroskedasticity-robust standard errors and are shown in parentheses. N denotes the number of observations. *, ** and *** represent $10 \%, 5 \%$ and $1 \%$ significance levels, respectively.

\begin{tabular}{|c|c|c|c|c|c|c|}
\hline & (1) & (2) & (3) & (4) & (5) & (6) \\
\hline \multirow[t]{2}{*}{ Bank } & $0.617^{* *}$ & $0.643^{* *}$ & $0.612 * *$ & $0.647^{* *}$ & $0.703^{* *}$ & $0.647 * *$ \\
\hline & $(0.034)$ & $(0.027)$ & $(0.036)$ & $(0.026)$ & $(0.019)$ & $(0.027)$ \\
\hline \multirow[t]{2}{*}{ Secondary } & $0.918 * * *$ & $0.862 * * *$ & $0.885^{* * *}$ & $0.816^{* * *}$ & $0.842 * * *$ & $0.850 * * *$ \\
\hline & $(0.000)$ & $(0.000)$ & $(0.000)$ & $(0.000)$ & $(0.000)$ & $(0.000)$ \\
\hline \multirow[t]{2}{*}{ Rule 415 shelf } & $0.602 * * *$ & $0.660 * * *$ & $0.962 * * *$ & $0.671 * * *$ & $0.738 * * *$ & $0.667 * * *$ \\
\hline & $(0.002)$ & $(0.001)$ & $(0.000)$ & $(0.001)$ & $(0.000)$ & $(0.001)$ \\
\hline \multirow[t]{2}{*}{ Share turnover } & $0.020^{* *}$ & $0.020^{* *}$ & $0.019^{* *}$ & $0.020^{* *}$ & $0.020^{* *}$ & $0.021 * *$ \\
\hline & $(0.021)$ & $(0.021)$ & $(0.030)$ & $(0.023)$ & $(0.026)$ & $(0.019)$ \\
\hline \multirow[t]{2}{*}{ Size } & $0.123^{* *}$ & $0.128^{* *}$ & $0.139 * *$ & $0.129^{* *}$ & 0.104 & $0.113 *$ \\
\hline & $(0.033)$ & $(0.026)$ & $(0.017)$ & $(0.025)$ & $(0.101)$ & $(0.086)$ \\
\hline \multirow[t]{2}{*}{ Proceeds/total assets } & -0.004 & -0.004 & -0.004 & -0.004 & -0.004 & -0.004 \\
\hline & $(0.202)$ & $(0.205)$ & $(0.202)$ & $(0.229)$ & $(0.191)$ & $(0.195)$ \\
\hline \multirow[t]{2}{*}{ Equity/total assets } & $0.007 *$ & $0.007^{*}$ & $0.007^{*}$ & $0.007 * *$ & $0.007 *$ & $0.007 * *$ \\
\hline & $(0.051)$ & $(0.050)$ & $(0.056)$ & $(0.048)$ & $(0.063)$ & $(0.050)$ \\
\hline \multirow[t]{2}{*}{ Stock run-up } & $-0.016 * * *$ & $-0.016 * * *$ & $-0.016^{* * *}$ & $-0.016 * * *$ & $-0.016^{* * *}$ & $-0.016 * * *$ \\
\hline & $(0.000)$ & $(0.000)$ & $(0.000)$ & $(0.000)$ & $(0.000)$ & $(0.000)$ \\
\hline \multirow[t]{2}{*}{ Stock volatility } & $-0.013^{* * *}$ & $-0.013^{* * *}$ & $-0.012 * * *$ & $-0.013^{* * *}$ & $-0.013 * * *$ & -0.009 \\
\hline & $(0.001)$ & $(0.001)$ & $(0.001)$ & $(0.001)$ & $(0.001)$ & $(0.248)$ \\
\hline \multirow[t]{2}{*}{ Market volatility } & -0.011 & -0.001 & -0.001 & -0.000 & 0.001 & -0.001 \\
\hline & $(0.401)$ & $(0.952)$ & $(0.953)$ & $(0.988)$ & $(0.960)$ & (0.918) \\
\hline \multirow[t]{2}{*}{ Market run-up } & $0.058 * * *$ & $0.059 * * *$ & $0.058 * * *$ & $0.059 * * *$ & $0.059 * * *$ & $0.058 * * *$ \\
\hline & $(0.000)$ & $(0.000)$ & $(0.000)$ & $(0.000)$ & $(0.000)$ & $(0.000)$ \\
\hline \multirow[t]{2}{*}{ 2007-09 financial crisis } & & $-0.626 * *$ & $-0.619 * *$ & $-0.607 * *$ & $-0.660 * *$ & $-0.633 * *$ \\
\hline & & $(0.024)$ & $(0.026)$ & $(0.029)$ & $(0.019)$ & $(0.023)$ \\
\hline \multirow[t]{2}{*}{ Firm commitment } & & & 0.398 & & & \\
\hline & & & $(0.110)$ & & & \\
\hline \multirow[t]{2}{*}{ Capital expenditure } & & & & -0.146 & & \\
\hline & & & & $(0.584)$ & & \\
\hline \multirow[t]{2}{*}{ Inverse elasticity } & & & & & -0.067 & \\
\hline & & & & & $(0.218)$ & \\
\hline \multirow[t]{2}{*}{ Arbitrage risk } & & & & & & -0.129 \\
\hline & & & & & & $(0.592)$ \\
\hline \multirow[t]{2}{*}{ Constant } & $-2.432 * * *$ & $-2.566^{* * *}$ & $-2.967 * * *$ & $-2.549 * * *$ & $-2.369 * * *$ & -1.201 \\
\hline & $(0.000)$ & $(0.000)$ & $(0.000)$ & $(0.000)$ & $(0.000)$ & $(0.642)$ \\
\hline $\mathrm{N}$ & 3763 & 3763 & 3763 & 3763 & 3709 & 3760 \\
\hline Adj. R-squared & 0.038 & 0.039 & 0.040 & 0.039 & 0.041 & 0.039 \\
\hline
\end{tabular}




\section{Table 3}

\section{Matched sample results}

This table shows the propensity score matching with the nearest neighbour of non-banks to compare cumulative abnormal stock returns in the interval period between -1 and 1 days for banks and non-banks. Panel A reports the probit model results, where the dependent variable is a bank dummy, and Panel B the difference in the cumulative abnormal stock returns between banks and matched non-banks. All explanatory variables are defined in Appendix 1 . $\mathrm{N}$ denotes the number of observations. $*$ and $* * *$ represent $10 \%$ and $1 \%$ significance levels, respectively.

Panel A: Probit model results

Proceeds ratio

\begin{tabular}{cc} 
Coefficients & Standard errors \\
\hline $0.016^{* * *}$ & 0.016 \\
0.005 & 0.005 \\
0.004 & 0.004 \\
$0.014 *$ & 0.014 \\
$0.017 * * *$ & 0.017 \\
$0.400^{* * *}$ & 0.400 \\
$0.305^{*}$ & 0.305
\end{tabular}

$\mathrm{N}$

6332

Pseudo R-square

$21.30 \%$

Panel B: Cumulative abnormal stock returns (CARs)

Nearest neighbour matching

CAR $(-1,1)$

\begin{tabular}{ccc} 
Banks & Non-banks & Difference \\
\hline$-0.150^{* * * *}$ & $-1.680^{* * *}$ & $1.530^{* * *}$ \\
166 & 166 &
\end{tabular}




\section{Table 4}

The impact of the 2007-09 financial crisis and the 2010 Dodd-Frank Act

This table shows the propensity score matching-based pairwise difference-in-difference analysis of the impact of the 2007-09 financial crisis and the passage of the Dodd-Frank Act in 2010 on the difference in cumulative abnormal stock returns in the interval period (-1, 1 days) for banks and non-banks. The dependent variable is the difference in CARs between banks and matched non-banks using the propensity score matching approach. 2007-09 financial crisis is a dummy variable, which equals 1 if the year is between 2007 and 2009, and 0 otherwise. Dodd-Frank Act is a dummy variable, which equals 1 if the year is 2010 or later, and 0 otherwise. Column (1) includes the entire sample from 1982 to 2012, column (2) the period from 2004 to 2012, and column (3) from 2007 to 2012. N denotes the number of observations. P-values are estimated using White's (1980) heteroskedasticity-robust standard errors and are shown in parentheses. $* *$ and $* * *$ represent $5 \%$ and $1 \%$ significance levels, respectively.

\begin{tabular}{lccc}
\hline & $(1)$ & $(2)$ & $(3)$ \\
\hline 2007-09 financial crisis & $-2.586^{* *}$ & $-3.118^{* *}$ & $(0.046)$ \\
Dodd-Frank Act & $(0.040)$ & & $5.962^{* *}$ \\
& & & $(0.021)$ \\
Constant & & $2.592^{* *}$ & -0.526 \\
& $2.060^{* * *}$ & $(0.014)$ & $(0.650)$ \\
N & $(0.000)$ & & 47 \\
Adj. R-squared & & 80 & 0.110 \\
\hline
\end{tabular}




\section{Figure 1}

Cumulative abnormal announcement stock returns (-1,1 days) of SEOs for banks versus non-banks during the sample period

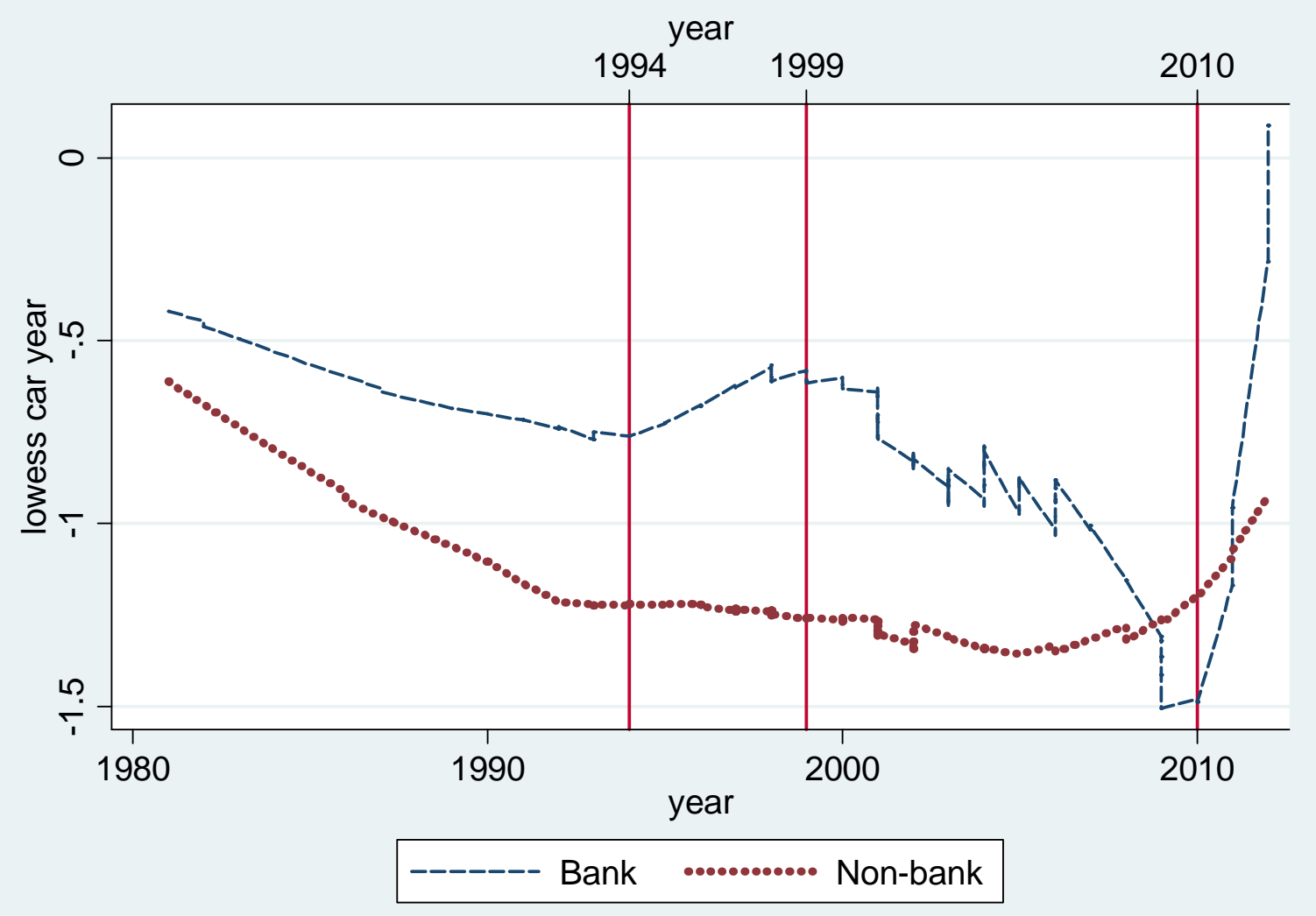




\begin{tabular}{|c|c|c|}
\hline Variable & Classification & Definition \\
\hline Bank & Firm-specific & 1 for banks, 0 otherwise \\
\hline Secondary & Issue-specific & 1 for shares being sold by existing shareholders, 0 otherwise \\
\hline Rule 415 shelf & Issue-specific & 1 if equity offering was shelf registered, 0 otherwise \\
\hline Share turnover & Firm-specific & Trading volume divided by the number of shares outstanding \\
\hline Size & Firm-specific & Natural logarithm of total assets denominated in US dollars \\
\hline Proceeds/total assets & Issue-specific & Relative size of the equity offering, calculated as the offering proceeds divided by total assets \\
\hline $\begin{array}{l}\text { Equity/total assets } \\
\text { Stock run-up }\end{array}$ & $\begin{array}{l}\text { Firm-specific } \\
\text { Firm-specific }\end{array}$ & $\begin{array}{l}\text { Total equity divided by total assets } \\
\text { Stock return over the window }(-60,-2) \text { relative to the announcement date }\end{array}$ \\
\hline Stock volatility & Firm-specific & $\begin{array}{l}\text { Annualized stock return volatility, calculated from daily stock returns over the window }(-250,-10) \text { relative to the equity } \\
\text { announcement date }\end{array}$ \\
\hline Market volatility & Market-specific & $\begin{array}{l}\text { Annualized market return volatility, calculated from daily returns on the S\&P } 500 \text { index over the window }(-240,-40) \\
\text { relative to the equity announcement date }\end{array}$ \\
\hline Market run-up & Market-specific & Stock market returns on S\&P 500 index over the window $(-60,-2)$ relative to the announcement date \\
\hline 2007-09 financial crisis & Market-specific & 1 for equity issued during years 2007 to 2009,0 otherwise \\
\hline Firm commitment & Issue-specific & 1 if the equity is issued as firm commitment, 0 otherwise \\
\hline Capital expenditure & Firm-specific & 1 if the intended use of proceeds is a capital expenditure, 0 otherwise \\
\hline Inverse elasticity & Issue-specific & $\begin{array}{l}\text { The natural log transformation of the absolute value of the daily raw return divided by the daily turnover, averaged over } \\
250 \text { trading days before the announcement date }\end{array}$ \\
\hline Arbitrage risk & Issue-specific & $\begin{array}{l}\text { The residual variance, expressed as a squared percentage of the market model OLS regression residual, estimated over the } \\
250 \text { trading days before the announcement date }\end{array}$ \\
\hline
\end{tabular}

